\title{
Modulation of collagen-induced arthritis by adenovirus-mediated intra-articular expression of modified collagen type II
}

\author{
Bo Tang 1, David L Cullins', Jing Zhou', Janice A Zawaski2, Hyelee Park1,3, David D Brand1,4, Karen A Hasty³, M \\ Waleed Gaber2, John M Stuart 1,4 , Andrew H Kang ${ }^{1,4}$ and Linda K Myers*5
}

\begin{abstract}
Introduction: Rheumatoid arthritis (RA) is a systemic disease manifested by chronic inflammation in multiple articular joints, including the knees and small joints of the hands and feet. We have developed a unique modification to a clinically accepted method for delivering therapies directly to the synovium. Our therapy is based on our previous discovery of an analog peptide (A9) with amino acid substitutions made at positions 260 (I to A), 261 (A to B), and 263 ( $F$ to N) that could profoundly suppress immunity to type II collagen (CII) and arthritis in the collagen-induced arthritis model (CIA).
\end{abstract}

Methods: We engineered an adenoviral vector to contain the CB11 portion of recombinant type II collagen and used PCR to introduce point mutations at three sites within $\left(\mathrm{CII}_{124-402,260 \mathrm{~A}, 261 \mathrm{~B}, 263 \mathrm{D})}\right)$ ( $(\mathrm{CCB} 11-\mathrm{A} 9)$ so that the resulting molecule contained the A9 sequence at the exact site of the wild-type sequence.

Results: We used this construct to target intra-articular tissues of mice and utilized the collagen-induced arthritis model to show that this treatment strategy provided a sustained, local therapy for individual arthritic joints, effective whether given to prevent arthritis or as a treatment. We also developed a novel system for in vivo bioimaging, using the firefly luciferase reporter gene to allow serial bioluminescence imaging to show that luciferase can be detected as late as 18 days post injection into the joint.

Conclusions: Our therapy is unique in that we target synovial cells to ultimately shut down T cell-mediated inflammation. Its effectiveness is based on its ability to transform potential inflammatory $T$ cells and/or bystander $T$ cells into therapeutic (regulatory-like) T cells which secrete interleukin (IL)-4. We believe this approach has potential to effectively suppress RA with minimal side effects.

\section{Introduction}

Rheumatoid arthritis (RA) is a systemic disease with polyarticular manifestation of chronic inflammation in multiple articular joints, including the knees and small joints of the hands and feet. The current systemic anti-TNF- $\alpha$ therapies ameliorate disease in $60 \%$ to $70 \%$ of RA patients [1]. However, biologics must be given systemically in relatively high dosages to achieve constant therapeutic levels in the joints, and significant side effects have been reported [2].

* Correspondence: Imyers@uthsc.edu

5 Department of Pediatrics, University of Tennessee Health Science Center, 50 North Dunlap, Room 401, Memphis TN 38163 USA

Full list of author information is available at the end of the article
Gene therapy may provide an effective alternative to drug delivery for the treatment of arthritis [3]. Although various strategies have been tested, those that target gene delivery to the synovial lining of joints have made the most experimental progress $[3,4]$. This strategy has shown efficacy in several experimental models of RA [57]. For this reason, we have developed a unique modification to a clinically acceptable method of gene delivery to allow delivery of the gene product directly to the synovium. Our therapy is based on our previous discovery of an analog peptide (A9) of type II collagen (CII) with amino acid substitutions made at positions 260 (I to A), 261 (A to B), and 263 (F to N) that could profoundly suppress immunity to CII and arthritis in the collagen- 
induced arthritis (CIA) model [8]. Such collagen peptides containing specially designed substitutions and expressed as a gene products may provide an ideal choice to be delivered to the joints.

We engineered an adenoviral gene-based therapy and showed that this treatment strategy provided a sustained, local therapy for individual arthritic joints. Our therapy is unique in that we target synovial cells to ultimately shut down $\mathrm{T}$ cell-mediated inflammation. Its effectiveness is based on its ability to transform potential inflammatory $\mathrm{T}$ cells and/or bystander $\mathrm{T}$ cells into therapeutic (regulatory-like) $\mathrm{T}$ cells [8]. They are potentially safer than current therapies because they contain a modification of an endogenous naturally occurring protein, used to interrupt the autoimmune $\mathrm{T}$ cell attack and allow for tissue repair. We believe this approach has the potential to become applicable for treatment of RA.

\section{Materials and methods}

\section{Preparation of tissue-derived type II collagen}

Native CII was solubilized from fetal calf articular cartilage by limited pepsin-digestion and purified as described earlier [9]. The purified collagen was dissolved in cold $0.01 \mathrm{M}$ acetic acid at $4 \mathrm{mg} / \mathrm{ml}$ and stored frozen at $-70^{\circ} \mathrm{C}$ until used.

\section{Animals}

DBA/1 mice were obtained from the Jackson Laboratories and raised in our animal facility. They were fed standard rodent chow (Ralston Purina Co., St. Louis, MO, USA) and water ad libitum. The environment was specific pathogen-free and sentinel mice were tested routinely for mouse hepatitis and Sendai viruses. All animals were kept until the age of 7 to 10 weeks before being used for experiments, which were conducted in accordance with approved Institutional Animal Care and Use Committee (IACUC) protocols.

\section{Immunization}

CII was solubilized in $0.01 \mathrm{M}$ acetic acid at a concentration of $4 \mathrm{mg} / \mathrm{ml}$ and emulsified with an equal volume of complete Freund's adjuvant (CFA) containing $4 \mathrm{mg} / \mathrm{ml}$ of Mycobacterium tuberculosis strain H37Ra (Difco Microbiology Products, Becton Dickinson, NJ, USA) [10]. Each mouse received $100 \mu \mathrm{g}$ of CII emulsified in CFA intradermally at the base of the tail.

\section{Generation of replication-defective, recombinant adenoviral vector expressing modified CB11}

Recombinant adenovirus carrying cDNA for rCB11-A9 was generated using a BD Adeno-X Expression System (BD Biosciences Clontech (San Jose, California, USA)), which incorporates the rCB11-A9 expression cassette into a replication-incompetent $(\Delta \mathrm{E} 1 / \Delta \mathrm{E} 3)$ human adenoviral type 5 (Ad5) genome. All work was conducted in accordance with approved Institutional Biosafety Committee (IBC) protocols. In brief, an 834 bp of full-length murine CB11 gene was PCR-amplified from murine spleen cDNA and cloned into the PCR2 vector (Invitrogen, Carlsbad, California, USA). We introduced three point mutations (I260A, A261B, and F263N) within the immunodominant $\mathrm{T}$ cell determinant of $\mathrm{CB} 11\left(\mathrm{CII}_{124-402}\right)$ to generate an rCB11-A9 construct. The rCB11-A9 cDNA was then excised with BamHI/EcoR I and subcloned into the same sites of the pShuttle2 vector to construct an rCB11-A9 specific expression cassette. For in vivo bioimaging analysis, a cDNA encoding the luciferase gene was also subcloned into the pShuttle2 to establish the Adeno-X-luciferase expression cassette. To produce recombinant adenoviral DNA containing rCB11-A9 or luciferase, we excised the expression cassettes from recombinant pShuttle2 plasmid DNA by digesting with ICeu I and PI-Sce I and ligated the expression cassettes with prelinearized BD Adeno-X Viral DNA (I-Ceu I and PI-Sce I digested). Low passage HEK293 cells were transfected with the resultant recombinant adenoviral DNA using the calcium phosphate method [11]. The recombinant adenoviral particles were harvested by lysing transfected cells. The resultant AdenoX-rCB11-A9 is a replication-incompetent recombinant adenovirus. High titer viral stocks (about $10^{8}$ to $10^{9}$ plaque forming units $(\mathrm{pfu}) / \mathrm{ml}$ ) were obtained by amplifying recombinant adenovirus in HEK 293 cells. A construct (pShuttle2-lacZ) was included in the BD Adeno-X Expression System and recombinant AdenoX-lacZ was generated as described above and used as a control. The recombinant adenoviral titers were determined by BD Adeno-X Rapid Titer Kit $[11,12]$.

\section{Production and purification of recombinant $\mathrm{CB} 11$ and CB11-A9}

In some experiments, a baculoviral expression system was used to produce $\mathrm{rCB} 11\left(\mathrm{CII}_{124-402}{ }^{\mathrm{bac}}\right)$ in insect cells essentially as described earlier [13]. The cDNA for both recombinant $\mathrm{CB} 11$ and $\mathrm{CB} 11-\mathrm{A} 9$ (rCB11 and rCB11-A9) were subcloned into a Gateway entry vector (Invitrogen, Carlsbad, California, USA) and validated. The resultant Gateway entry vectors containing either rCB11 or rCB11A9 were ligated with BaculoDirect Linear DNA (Invitrogen, Carlsbad, California, USA) and transfected into Sf9 insect cells. Supernatants from lysed insect cells were collected and screened for expression by performing SDSPAGE and western blot analysis. After validated, high titers of recombinant baculovirus were obtained by reinfecting Sf9 cells twice and supernatants collected from lysed cells. To express the recombinant proteins $\mathrm{Hi} 5$ cells was infected with high titer of baculovirus. Supernatants from cultured $\mathrm{Hi} 5$ cells were harvested by centrifugation and the recombinant proteins purified by gel filtration 
and cation exchange chromatography, and dialyzed in dilute acetic acid.

\section{Synovial injections}

The hind ankle joints of DBA/1 mice were injected intraarticularly with $10 \mathrm{ul}$ of adenoviral vector $1 \times 10^{7} \mathrm{pfu}$ of adenovirus, containing the DNA for either luciferase, rCB11-A9, or Lac-Z. In some experiments, selected mice were injected intraperitoneally with luciferin, and the expression of the transgene (luciferase) was detected by bioluminescent imaging using a liquid nitrogen cooled CCD camera (Photometric Chemipro, Roper Scientific, NJ, USA) mounted on a dark box one hour later. Images were acquired and analyzed using Metamorph software (Universal Imaging Co., Dowlington, PA, USA).

\section{Measurement of the incidence and severity of arthritis}

The incidence and severity of arthritis were determined by visually examining each forepaw and hindpaw and scoring them on a scale of 0 to 4 as described previously [10]. Scoring was conducted by two examiners, one of whom was unaware of the identity of the treatment groups. Each mouse was scored thrice weekly beginning three weeks post immunization and continuing for eight weeks. The incidence of arthritis (number of animals with one or more arthritic limbs) and mean severity score (sum of the severity scores/total number of animals in the group) was recorded at each time point.

In a prevention protocol, four groups of $10 \mathrm{DBA} / 1$ mice each were administered intra-articularly in the ankles, either adenoX-rCB11-A9 or adenoX-LacZ. The mice were immunized with CII/CFA either three or seven days after the injection.

In a treatment protocol, groups of three DBA/1 mice were immunized with CII/CFA and at the time arthritis reached a severity score of two or greater, the mice were administered intra-articularly in the hind ankles either adenoX-rCB11-A9 or adenoX-LacZ.

\section{Measurement of serum antibody titers}

Mice were bled at six weeks after immunization and sera were analyzed for antibodies reactive with native CII using a modification of an ELISA previously described [10]. Serial dilutions of a standard serum were added to each plate. From these values, a standard curve was derived by computer analysis using a four-parameter logistic curve. Results are reported as units of activity, derived by comparison of test sera with the curve derived from the standard serum which was arbitrarily defined as having 50 units of activity. Reactivity to CII was not detected in sera obtained from normal mice.

\section{Measurement of cytokines}

Groups of three DBA/1 mice were administered intraarticularly either adenoX-rCB11-A9 or adenoX-LacZ and the mice were immunized with CII/CFA three days after the injection. Draining lymph node cells were harvested 14 days after the immunization and cultured $\left(5 \times 10^{6}\right.$ cells $/ \mathrm{ml}$ ) with $100 \mu \mathrm{g} / \mathrm{ml}$ of either the mouse collagen immunodominant peptide, Ova (negative control), or purified protein derivative (PPD) (positive control). Supernatants were collected 72 hours later and analyzed for the presence of multiple cytokines (IL-4, IL-5, IL-10, IL-2, interferon (IFN) $\gamma$, and IL-17 by a Bio-plex mouse cytokine assay (Bio-Rad, Hercules, CA, USA) according to the manufacturer's protocol. Values are expressed as picograms per $\mathrm{ml}$ and represent the mean values for each group.

\section{Statistical analysis}

The incidence of arthritis in various groups of mice was compared using Fisher's Exact Test. Mean severity scores and antibody levels were compared using Student's t test.

\section{Results}

An adenoviral construct efficiently transfers an exogene into arthritic synovial tissues in collagen-induced arthritis Using a replication-defective, recombinant adenovirus, we incorporated the cDNA for lac-Z, and assessed the transfection efficiency of the recombinant adenovirus delivered into arthritic ankles of DBA/1 mice previously immunized with CII/CFA. Each hind ankle was injected intra-articularly with $10^{7} \mathrm{pfu}$ of the adenoviral particles. Forty-eight hours later, the animals were sacrificed and histology was performed on the involved joints. As shown in Figure 1, staining with $\beta$-galactosidase clearly demonstrated that the adenovirus-expressed gene product was present in synovial cells, lining the surface of the synovium near the cartilage surface (Figure 1). Although most of the transfected cells are fibroblast-like synoviocytes, a smaller number of monocyte-like synovial cells were also transfected. These data confirm that arthritic synovial cells can be readily transfected with adenoviral constructs and that an adenovirus carrying gene can be efficiently expressed.

\section{Development of the baculovirus construct for modified collagen ( $\mathrm{rCB} 11-\mathrm{A} 9$ ) expression and evaluation of its immunogenicity}

To develop a unique collagen-based therapy, we built upon our previous work demonstrating that a synthetic peptide of CII, which contained three amino acid substitutions (A9), could effectively suppress arthritis. We used PCR to introduce three point mutations within the CB11

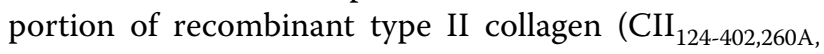
261B, 263D), (rCB11-A9) so that the resulting molecule contained the A9 sequence at the exact site of the wild-type sequence. To test for safety, we developed a baculovirus construct and expressed the rCB11-A9 protein in droso- 


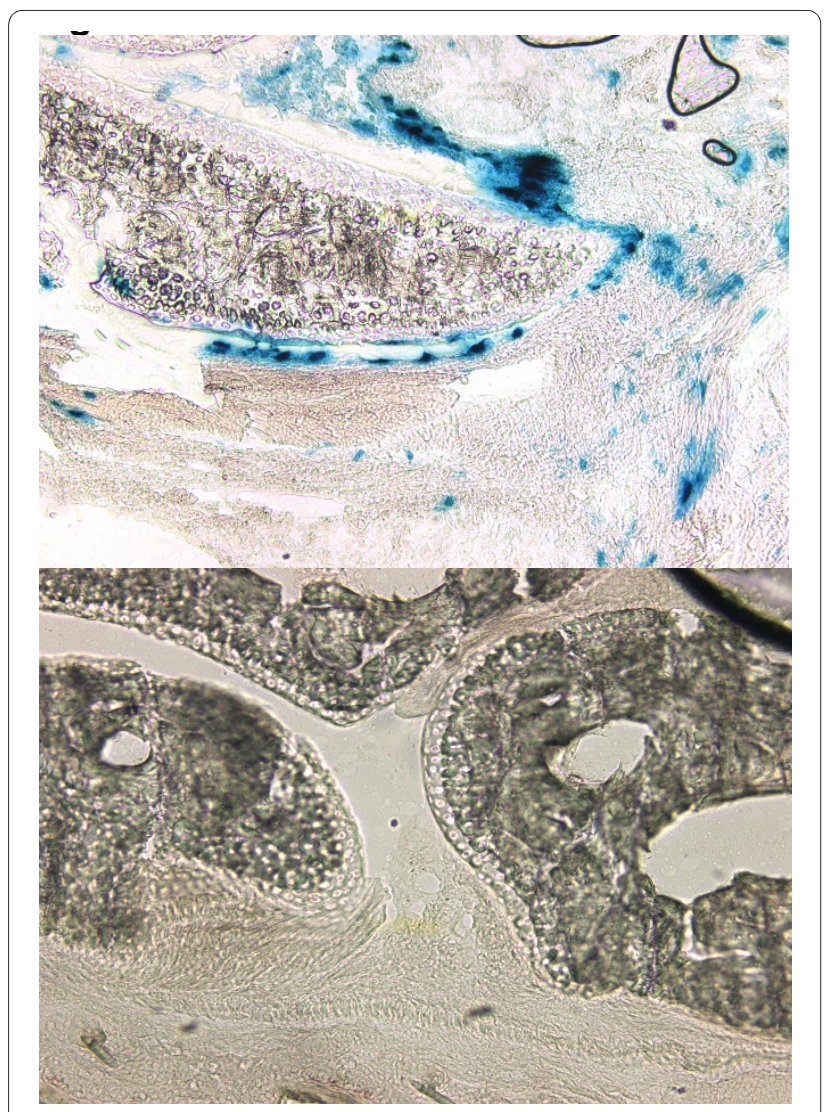

Figure 1 Localization of adenovirus-expressed recombinant protein in arthritic mouse paws. Two DBA/1 mice were immunized with type II collagen/complete Freund's adjuvant and one week later injected intra-articularly (into hind ankles) with $10 \mu \mathrm{l}$ containing $10^{\times 7}$ total plaque forming units adenoviral particles encoding Lac-Z. The animals were sacrificed 48 hours later and the tissues photographed using a reverse phase microscope (50x). In the upper panel, the tissues were incubated with beta galactosidase substrate. The majority of the cells containing Lac-Z (upper panel, stained blue) appear to be fibroblastlike synoviocytes lining the surface of the synovium, although staining can also be detected in monocyte-like synoviocytes. The uninjected hindpaws were used as controls for each animal (lower panel). The data shown are representative of data obtained by analyzing multiple sections of each hindpaw.

phila cells, because insect cells express a modest activation of lysine hydroxylase and hydroxylysine glycosyltransferase, allowing partial glycosylation of the product. This system closely mimics the post-translational system of mammalian cells. The baculovirusexpressed collagen was purified, emulsified with CFA, and used to immunize DBA/1 mice to observe for the development of arthritis. We found that rCB11-A9 was unable to induce either arthritis or antibodies to CII (Table 1). On the other hand, the unmodified control rCB11-induced arthritis at its expected incidence of $40 \%$ as well as inducing a significant antibody response to murine CII (Table 1). These data suggest that rCB11-A9 will be safer than many conventional therapies, if used to treat arthritis because it is non-immunogenic and nonarthritogenic.

\section{Development of a method for in vivo bioimaging to track the duration of gene expression}

Noninvasive bioimaging is an exciting new development that can be applied to clinical diseases to monitor the duration of gene expression and determine the extent of the therapeutic effect. As adenoviral constructs typically can be transcribed but not replicated with cell division, it was important to predict the length of time the introduced therapy might be effective. We developed a system for in vivo bioimaging in which the firefly luciferase reporter gene was incorporated into our adenoviral vector and this construct was injected into murine ankle joints. Serial bioluminescence imaging of gene expression was performed on days 1, 3, 12 and 18 following intraperitoneal injection of luciferin, the substrate of luciferase. As shown in Figure 2, the injected sites of joints clearly showed the expression of luciferase, as indicated by the green luminescent color and the expression of luciferase could be detected as late as 18 days post injection. By day 21 the green color was no longer detectable. Taken together, these data confirm that a transgene carried by the adenoviral vector gene can be efficiently transferred into the joints and a sustained release of expression can be successfully achieved.

\section{Evaluation of the potency of the AdenoX-rCB11-A9 construct in suppression of $\mathrm{CIA}$}

All the previous data suggest that local expression of rCB11-A9 in arthritic joints will be able to effectively modulate CIA. To test this hypothesis the rCB11-A9 was incorporated into the adenoviral genome and the resulting construct (AdenoX-rCB11A9) tested. To evaluate potency in the treatment of arthritis, DBA/1 mice were injected intra-articularly (in the hind ankles) with the adenoX-rCB11-A9 either three or seven days prior to immunization with CII/CFA and were observed for the development of arthritis. Control mice were injected with adenoX-lacZ. As predicted, the mice treated with the adenoX-rCB11-A9 demonstrated a significant decrease in the severity of arthritis as manifested by the severity scores and visual inspection (Figure 3, panels a and b). The control adenoX-Lac-Z construct had no effect. Concordant with a decrease in the incidence and severity of arthritis, antibody production to CII was significantly decreased (Table 2). The hindpaws injected with AdenoX-rCB11A9 were profoundly affected when compared with adenoX-lacZ injected control hindpaws, (severity scores of 0 vs $2.8 \pm 2.7, P \leq 0.025$ if injected three days prior to immunization and 0 vs $2.2 \pm 1.8, P \leq 0.01$ if injected seven days prior to immunization). The noninjected forepaws developed arthritis with attenuated 
Table 1: A9-modified recombinant CB11 is not arthritogenic

\begin{tabular}{|c|c|c|}
\hline Format of collagenous immunogena & Incidence ${ }^{b}$ & Antibodies to CIIc \\
\hline rCB11-A9/CFA & $0 / 5(0 \%)$ & $2.5 \pm 1, P<0.05$ \\
\hline rCB11/CFA & $2 / 5(40 \%)$ & $21.3 \pm 5$ \\
\hline \multicolumn{3}{|c|}{$\begin{array}{l}\text { a. The baculovirus-expressed products, both rCB11 (recombinant } \mathrm{Cll}_{124-402)} \text { ) and rCB11-A9 (recombinant } \mathrm{Cl} \mathrm{I}_{124-402,260 \mathrm{~A}, 261 \mathrm{~B}, 263 \mathrm{D}} \text { ) were } \\
\text { collected, emulsified with complete Freund's adjuvant (CFA), and used to immunize groups of five DBA/1 mice to observe for the } \\
\text { development of arthritis. We found that modified rCB11-A9 was unable to induce either arthritis or significant antibody titers to type II } \\
\text { collagen (CII) while the control unmodified rCB11-induced arthritis at its expected incidence of } 40 \% \text { as well as inducing a greater antibody } \\
\text { response to murine CII. } \\
\text { b. Incidence is reported at six weeks following immunization. }\end{array}$} \\
\hline
\end{tabular}

severity (severity scores of $1.3 \pm 1.5$ vs $4.8 \pm 2.1, P \leq 0.01$ when treated three days prior, to imunization or $1.8 \pm 2 \mathrm{vs}$ $4.8 \pm 1.5, P \leq 0.01$ when treated seven days prior to immunization). These data indicate that therapy with

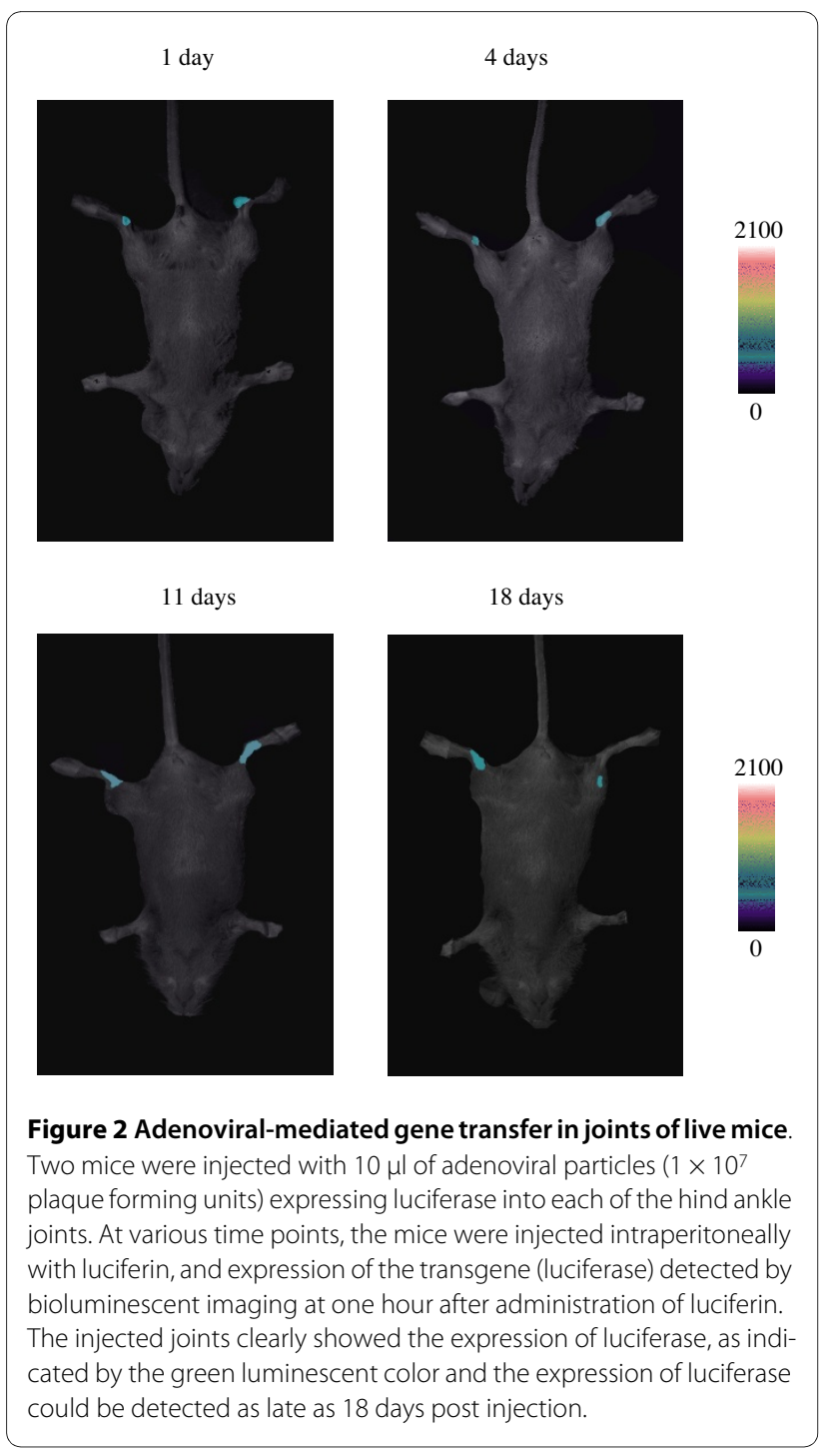

adenoX-rCB11-A9 significantly down regulated the immune responses to $\mathrm{CII}$ in vivo and attenuated the development of arthritis.

\section{Mechanism of suppression}

We have reported that a major component of the mechanism of action for the synthetic peptide analog A9 is its ability to cause $\mathrm{T}$ cells to secrete a suppressive cytokine profile. Its effectiveness is based on its ability to transform potential inflammatory $\mathrm{T}$ cells and/or bystander $\mathrm{T}$ cells into therapeutic (regulatory-like) $\mathrm{T}$ cells $[8,14]$.

\section{Table 2: AdenoX-rCB11-A9 treatment suppresses anti-CI antibodies}

\section{Antibodies to $\mathrm{Cll}$ in treated mice}

Treatment ${ }^{a} \quad$ Antibodies to $\mathrm{ClI}^{\mathrm{b}}$

AdenoX-rCB11-A9 (imm CII/ $\quad 19.6 \pm 2, P<0.05$
CFA 3 days later)

AdenoX-rCB11-A9 (imm CII/ $\quad 16.2 \pm 2 P<0.005$

CFA 7 days later)

AdenoX-lacZ (imm CII/CFA $3 \quad 37.2 \pm 10$

days later)

AdenoX-lacZ (imm CII/CFA $7 \quad 45.0 \pm 9$

days later)

a. Four groups of $10 \mathrm{DBA} / 1$ mice each were administered intraarticularly either adenoX-rCB11-A9 (adenoviral construct with

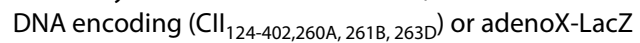

(adenoviral construct with DNA encoding LacZ). The mice were immunized with type II collagen/complete Freund's adjuvant (CII/CFA) either three or seven days after the injection and sera was collected six weeks after the immunization to test for antibodies to CII. As noted the adenoX-rCB11-A9 was extremely effective at suppressing the development of antibodies to CII, irregardless of whether the mice were immunized three days or seven days later.

b. Antibody levels were measured by ELISA and reported as arbitrary units based on comparison to a standard antiserum run simultaneously. 
(a)

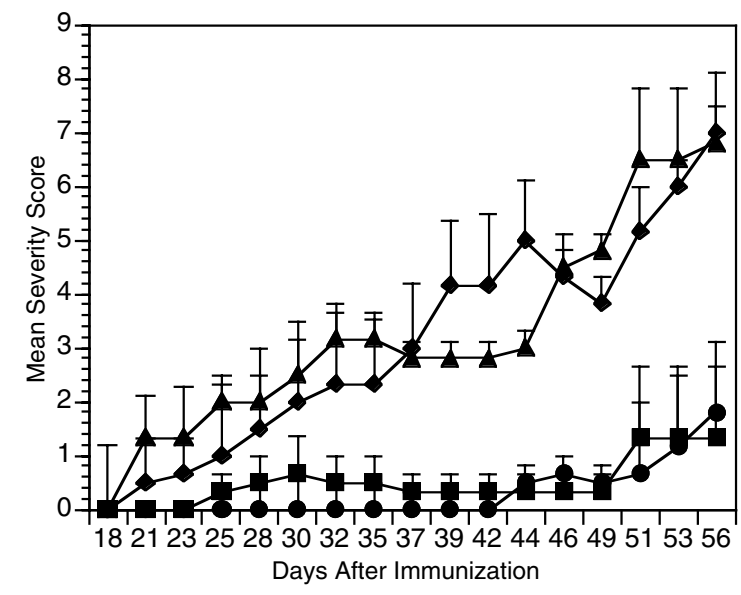

(b)
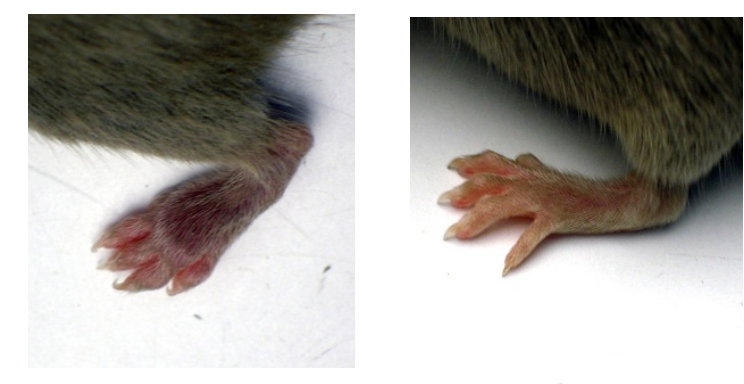

Figure 3 Treatment with adenoX-rCB11-A9 can prevent CIA. (a) Groups of 10 DBA/1 mice were administered intra-articularly either adenoX-rCB11-A9 (square, circle) or adenoX-LacZ (triangle, diamond). The mice were immunized with type II collagen/complete Freund's adjuvant either three (square, triangle) or seven (circle, diamond) days after the injection and all mice were observed for the development of arthritis. The data points reflect the mean severity score (sum of the severity scores/total number of animals in the group) at each time point. As shown the adenoX-rCB11-A9 was extremely effective at preventing the development of arthritis, whether the mice were immunized three days prior to immunization (final severity scores $1.3 \pm 1.5$ vs $6.8 \pm 5.3, P$ $\leq 0.025$ ) or seven days prior to immunization (final severity scores $1.8 \pm$ 2.0 vs $7.0 \pm 2.5, P \leq 0.005$ ). The final incidence of arthritis was (square $=$ $20 \%$, triangle $=90 \%, P \leq 0.003$ ) and (circle $=20 \%$, diamond $=100 \%, P \leq$ 0.0004). (b) Photographs of an arthritic hind paw from a DBA/1 mouse injected with adenoX-lacZ (left panel) and a hind paw from a DBA/1 mouse injected with adenoX-rCB11-A9 (right panel).

Based on our previous observation that the activated antigen-specific $\mathrm{T}$ cells found in draining lymph nodes can accurately reflect the $\mathrm{T}$ cell responses of arthritic joints [15], we examined the secretion of a panel of cytokines IFN- $\gamma$ and IL-2 (Th1), IL-10 and IL-4 (Th2) and IL17 (Th17), by testing supernatants from draining lymph node cells of mice cultured with the murine immunodominant determinant. We found that following treatment with adenoX-CB11-A9, the Th1 and Th17 cytokine responses to murine $\mathrm{CII}$ were significantly decreased compared with those induced following treatment with adenoX-lacZ. Similarly, the Th2 cytokines IL-5 and IL-10 were decreased. On the other hand, treatment with the adenoX-rCB11-A9 induced a significantly greater IL-4 response to murine $\mathrm{CII}$ when compared with the lac- $\mathrm{Z}$ control (Table 3). These data are consistent with the concept that IL-4 has a unique role in the suppression of arthritis that is only partially duplicated by other Th2type cytokines in the absence of IL-4 [16]. Taken together these data suggest that the adenoX-rCB11-A9 therapy may work by inducing a population of $\mathrm{T}$ cells to redirect their cytokine response to secrete predominantly IL-4, a cytokine known to ameliorate arthritis. The ability to induce a population of regulatory-like $\mathrm{T}$ cells to secrete suppressive cytokines in the presence of murine $\mathrm{CII}$ as well as the ability to redirect inflammatory cells toward a more suppressive phenotype may explain the profound downregulatory effects adenoX-rCB11-A9 has on CIA.

\section{Potency of AdenoX-rCB11-A9 in suppression of CIA when injected after the onset of arthritis}

In clinical situations, gene therapy is more likely to be used therapeutically rather than to prevent disease. To determine the effectiveness of this treatment on wellestablished arthritis, we immunized mice with CII/CFA and at the onset of arthritis (severity score greater than two), we introduced the adenoX-rCB11-A9 into the joints. As shown in Figure 3, the mice injected with the adenoX-rCB11-A9 had a reversal of arthritis, reaching severity scores of 0 within five days and the modulation of arthritis lasted approximately three weeks after the injection. Control mice injected with the adenoX-lacZ control did not improve and progressed to develop a more severe arthritis (Figure 4). The time course for the modulation of arthritis fits quite accurately with the time course predicted by the bioimaging data.

\section{Discussion}

Our aim was to engineer an adenoviral-based therapy designed to make synovial cells secrete a modified naturally produced molecule, type II collagen, thereby providing a sustained, local therapy for individual arthritic joints. This approach is attractive because joints are discrete, accessible cavities that can be readily injected. Many different genes have been evaluated for their ability to treat animal models of RA [17]. These have led to several clinical trials, confirming the feasibility and in a preliminary fashion, safety of gene transfer to human arthritic joints $[3,4,18,19]$.

Recently, several studies using adenoviral-mediated gene transfer of therapeutic genes for animal model treatment have been reported [7,20-22]. Adenoviruses carry their genetic material in the form of double-stranded 


\begin{tabular}{|c|c|c|c|c|c|c|c|}
\hline \multirow[b]{2}{*}{ Treatment } & \multirow[b]{2}{*}{ Antigen } & \multicolumn{6}{|c|}{ Cytokines(pg/ml) } \\
\hline & & IL-2 & IFN- $\gamma$ & IL-17 & IL-4 & IL-5 & IL-10 \\
\hline AdenoX-Lac-z & Ova & $131 \pm 12$ & $137 \pm 14$ & $280 \pm 22$ & $1 \pm 1$ & $82 \pm 10$ & $18 \pm 8$ \\
\hline AdenoX-Lac-z & Collagen peptide & $1,405 \pm 120$ & $643 \pm 25$ & $6,364 \pm 220$ & $7 \pm 3$ & $762 \pm 44$ & $214 \pm 17$ \\
\hline AdenoX-Lac-z & PPD & $631 \pm 50$ & $2,451 \pm 50$ & $8,612 \pm 267$ & $3 \pm 2$ & $820 \pm 63$ & $262 \pm 21$ \\
\hline AdenoX-rCB11A9 & Ova & $120 \pm 15$ & $164 \pm 22$ & $250 \pm 25$ & $2 \pm 1$ & $75 \pm 8$ & $16 \pm 9$ \\
\hline AdenoX-rCB11A9 & Collagen peptide & $152 \pm 14$ & $143 \pm 15$ & $286 \pm 25$ & $44 \pm 6$ & $203 \pm 21$ & $47 \pm 11$ \\
\hline $\begin{array}{l}\text { AdenoX } \\
\text { rCB11A9 }\end{array}$ & PPD & $776 \pm 62$ & $2,620 \pm 232$ & $8,633 \pm 547$ & $2 \pm 2$ & $778 \pm 83$ & $245 \pm 26$ \\
\hline \multicolumn{8}{|c|}{$\begin{array}{l}\text { Groups of three DBA/1 mice were administered intra-articularly either adenoX-rCB11-A9 or adenoX-LacZ and the mice were immunized with } \\
\text { type II collagen/complete Freund's adjuvant (CII/CFA) three days after the injection. Draining lymph node cells were harvested } 14 \text { days after } \\
\text { the immunization and cultured }\left(5 \times 10^{6} \mathrm{cells} / \mathrm{ml}\right) \text { with } 100 \mu \mathrm{g} / \mathrm{ml} \text { of the indicated antigens, either Ova (negative control), the mouse collagen } \\
\text { immunodominant wild type peptide, or Purified Protein Derivative (PPD) (positive control). Supernatants were collected } 72 \text { hours later and } \\
\text { analyzed for the presence of the indicated cytokines. Values are expressed as picograms per ml and represent the mean values for each group. } \\
\text { Cytokines IL-2, IFN- } \mathrm{I} \text {, IL-17, IL-5, and IL-10 were all significantly higher in response to the mouse collagen immunodominant peptide in the } \\
\text { adenoX-lacZ treated mice compared with mice treated with adenoX-rCB11-A9 }(P \leq 0.05) \text {. On the other hand, IL-4 was significantly greater in } \\
\text { the mice treated with aden-rCB11-A9 }(P \leq 0.05) \text {. }\end{array}$} \\
\hline
\end{tabular}

DNA. When these viruses infect a host cell, the DNA molecule is left free in the nucleus of the host cell, and is transcribed, but not replicated. The advantages of this therapy are two-fold [23]. The treatment gives a sustained release of the material directly into the joint cavity, greatly decreasing the amount of material required and the number of injections necessary. Second, the absence of integration into the host cell's genome lessens the possibility of permanent side effects, and prevents the possibility of malignant-type transformations. Although concerns about the safety of adenovirus vectors have been raised, newer genetically crippled versions of the virus together with modified or deleted capsid sequences have demonstrated an increased safety and potential for stable transgene expression [23].

Most gene transfer strategies for treatment of RA are currently broad based, designed for introducing cytokines [3,4,18-22]. The capability of collagen peptides to act locally to induce $\mathrm{T}$ cells to secrete suppressive cytokines in a limited environment makes them interesting as potential therapeutic reagents in suppressing RA. Our therapy is based on our previous discovery of an analog peptide (A9) with amino acid substitutions made at positions 260 (I to A), 261 (A to B), and 263 (F to N) that profoundly suppressed immunity to CII and arthritis. In a mouse model of RA, A9 protein therapy achieved a dramatic arrest in the overall disease progression as judged by clinical, histopathological, and immunological manifestations of arthritis [8]. We now demonstrate in vivo immunomodulatory properties of rCB11-A9, supporting its therapeutic potential in the treatment of inflammatory autoimmune disorders. Such collagen peptides containing specially designed substitutions and expressed as gene products may provide an ideal choice to be delivered to the joints. The advantages over conventional therapies include the ease with which they can be injected at the site of the inflammation, targeting the specific arthritogenic lymphocytes that initiate and perpetuate joint inflammation, and transforming potential inflammatory $\mathrm{T}$ cells and/or bystander $\mathrm{T}$ cells into therapeutic (regulatory-like) $\mathrm{T}$ cells. Our results suggest that the effects are primarily localized to the joints, although we have not performed biodistribution studies. They are potentially safer than current therapies because they contain a modification of an endogenous naturally occurring protein. The use of the gene therapy overcomes the problems of rapid degradation and short half-life of small synthetic proteins in vivo.

Another great advantage of gene delivery to the synovial cells is that they contain the enzymatic apparatus to apply post-translational modifications, including the hydroxylation and glycosylation of lysine residues, which occur in chondrocyte synthesized CII, but not synthetic peptides. It is known that CII peptide fragments derived from the cyanogen bromide digestion of native $\mathrm{CII}$ are immunologically more active than chemically synthesized peptides $[24,25]$. It is now generally accepted that part of the $\mathrm{T}$ cell response to cartilage-derived CII is dependent upon the presence of glycosylated determinants, which stabilize major histocompatibility complex/ 


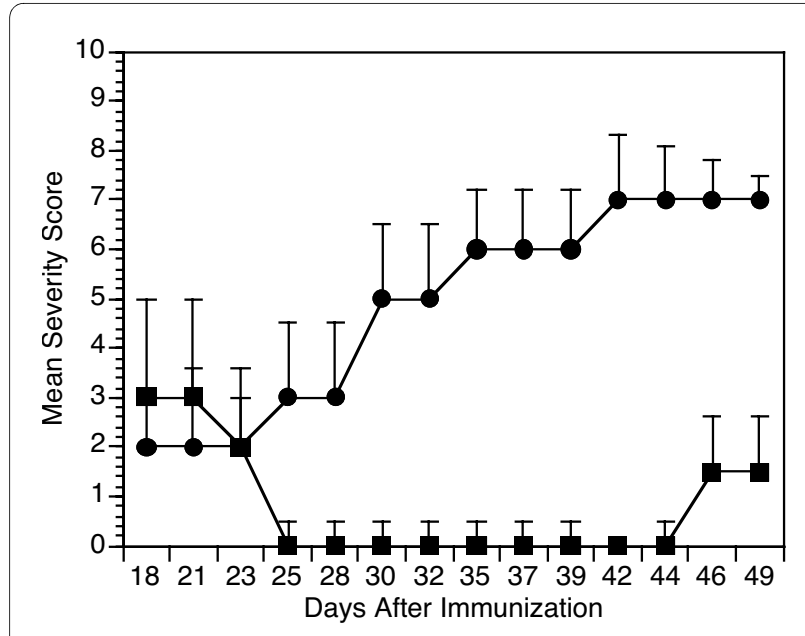

Figure 4 Treatment with adenoX-rCB11-A9 can suppress collagen-induced arthritis when administered after the development of established arthritis. Groups of 3 DBA/1 mice were immunized with type II collagen/complete Freund's adjuvant and at the time arthritis reached a severity score of two or greater, the mice were administered intra-articularly either adenoX-rCB11-A9 (square) or adenoXLacZ (circle). All mice were observed for the development of arthritis. The data points reflect the mean severity score (sum of the severity scores/total number of animals in the group) at each time point. As noted the adenoX-rCB11-A9 was extremely effective at treating established arthritis, causing a reversal of the severity of the disease which persisted for a full two weeks (severity scores of 0 vs $5.1 \pm 2.1, P<0.05$ on day 30 after immunization and 0 vs $7.1 \pm 2.2 ; P \leq 0.05$ on day 44 ).

$\mathrm{T}$ cell receptor (MHC/TCR) interaction or act as part of the epitope [24-27].

Despite these advantages, it should be noted that there is no consensus concerning the ideal vector for human gene therapies. For example, patients can carry pre-existing neutralizing antibodies to adenoviral vectors or develop them after the first injections, reducing their effectiveness. Although scientific breakthroughs continue to move gene therapy toward mainstream medicine, future research should enhance clinical applications of a collagen-based gene therapy for RA.

\section{Conclusions}

In summary, our studies demonstrate that: recombinant CB11-A9 adenovirus can efficiently transfer and express exogenes in joints and synovial tissue; the expression persists for at least 18 days after the injection; and this type of therapy is effective at both prevention and treatment of autoimmune arthritis. These data strongly support our hypothesis that adenoviral-mediated modified collagentype therapies can suppress arthritis and transform activated $\mathrm{T}$ cells and bystander $\mathrm{T}$ cells into therapeutic (regulatory-like) $\mathrm{T}$ cells. Gene therapy has emerged as an effective and promising therapeutic strategy for RA [3]. To this end, local gene delivery can provide an alternative approach to achieve high, long-term expression of biolog- ics, optimizing the therapeutic efficacy and minimizing systemic exposure. Future analogs can be optimized for binding to the human MHC [28]. Our data using adenoXrCB11-A9 in the CIA animal model convincingly supports the possibility of a collagen-based gene therapy for RA.

\section{Abbreviations}

bp: base pair; Cll: type II collagen; CFA: complete Freud's adjuvant; CIA: collagen-induced arthritis; ELISA: enzyme-linked immunosorbent assay; IACUC: Institutional Animal Care and Use Committee; IBC: Institutional Biosafety Committee; IFN: interferon; IL: interleukin; MHC/TCR: major histocompatibility complex/T cell receptor; PCR: polymerase chain reaction; pfu: plaque forming units; PPD: purified protein derivative; RA: rheumatoid arthritis; TNF: tumor necrosis factor.

\section{Competing interests}

The authors declare that they have no competing interests.

\section{Authors' contributions}

$\mathrm{BT}, \mathrm{DB}$, and JZ developed the collagen and adenoviral constructs, JAZ and MWG performed the bioimaging studies, HP and KH performed the synovial histology studies, DC, JMS, AHK, and LKM performed the animal studies and participated in the design of the experiments. All authors read and approved the final manuscript.

\section{Acknowledgements}

This work was supported, in part, by USPHS Grants AR-55661, AR-55266, and program-directed funds from the Department of Veterans Affairs and the Arthritis Foundation.

\section{Author Details}

1Department of Medicine, University of Tennessee Health Science Center, 956 Court Avenue, Memphis, Tennessee 38163, USA, ${ }^{2}$ Department of Biomedical Engineering, University of Tennessee Health Science Center, 920 Madison, Suite 407, Memphis, Tennessee 38163 USA, ${ }^{3}$ Department of Orthopedics, University of Tennessee Health Science Center, 1211 Union Avenue, Suite 520, Memphis, Tennessee 38104 USA, ${ }^{2}$ Research Service, Veterans Affairs Medical Center, 1030 Jefferson Avenue, Memphis TN 38104 USA and ${ }^{5}$ Department of Pediatrics, University of Tennessee Health Science Center, 50 North Dunlap, Room 401, Memphis TN 38163 USA

Received: 16 December 2009 Revised: 12 April 2010

Accepted: 8 July 2010 Published: 8 July 2010

\section{References}

1. Kukar M, Petryna O, Efthimiou P: Biological targets in the treatment of rheumatoid arthritis: a comprehensive review of current and indevelopment biological disease modifying anti-rheumatic drugs. Biologics 2009, 3:443-457.

2. Lakatos PL, Miheller P: Is there an increased risk of lymphoma and malignancies under anti-TNF therapy in IBD? Curr Drug Targets 2010, 11:179-86.

3. Evans $\mathrm{CH}$, Ghivizzani SC, Robbins PD: Gene therapy of the rheumatic diseases: 1998 to 2008. Arthritis Res Ther 2009, 11:209.

4. Mease PJ, Wei N, Fudman EJ, Kivitz AJ, Schechtman J, Trapp RG, Hobbs KF, Greenwald M, Hou A, Bookbinder SA, Graham GE, Wiesenhutter CW, Willis L, Ruderman EM, Forstot JZ, Maricic MJ, Dao KH, Pritchard CH, Fiske DN, Burch FX, Prupas HM, Anklesaria P, Heald AE: Safety, tolerability, and clinical outcomes after intraarticular injection of a recombinant adenoassociated vector containing a tumor necrosis factor antagonist gene: results of a phase 1/2 Study. J Rheumatol 2010, 37:692-703.

5. Rabinovich GA, Daly G, Dreja H, Tailor H, Riera CM, Hirabayashi J, Chernajovsky Y: Recombinant galectin-1 and its genetic delivery suppress collagen-induced arthritis via T cell apoptosis. J Exp Med 1999, 190:385-398.

6. Chan JM, Villarreal G, Jin WW, Stepan T, Burstein H, Wahl SM: Intraarticular gene transfer of TNFR:Fc suppresses experimental arthritis with 
reduced systemic distribution of the gene product. Mol Ther 2002, 6:727-736.

7. Khoury M, Courties G, Fabre S, Bouffi C, Seemayer CA, Vervoordeldonk MJ, Tak PP, Jorgensen C, Apparailly F: Adeno-associated virus type 5mediated intraarticular administration of tumor necrosis factor small interfering RNA improves collagen-induced arthritis. Arthritis Rheum 2010, 62:765-770.

8. Myers LK, Tang B, Rosioniec EF, Stuart JM, Kang AH: An altered peptide ligand of type Il collagen suppresses autoimmune arthritis. Crit Rev Immunol 2007, 27:345-356.

9. Stuart JM, Cremer MA, Dixit SN, Kang AH, Townes AS: Collagen-induced arthritis in rats. Comparison of vitreous and cartilage-derived collagens. Arthritis Rheum 1979, 22:347-352.

10. Rosloniec EF, Kang AH, Myers LK, Cremer MA: Collagen-induced arthritis. In Current Protocols in Immunology Edited by: Coico R, Shevach E. New York, NY: Wiley \& Sons; 2010:15.5.1-15.5.25.

11. Kingston RE, Chen CA, Rose JK: Calcium phosphate transfection. Curr Protoc Mol Biol 2003, Chapter 9:Unit 9.1.

12. Lu Y, Zhang Y, Steiner MS: Efficient identification of recombinant adenoviruses by direct plaque screening. DNA Cell Biol 1998, 17:643-645

13. Nokelainen M, Helaakoski T, Myllyharju J, Notbohm H, Pihlajaniemi T, Fietzek PP, Kivirikko KI: Expression and characterization of recombinant human type II collagens with low and high contents of hydroxylysine and its glycosylated forms. Matrix Biol 1998, 16:329-338.

14. Myers LK, Tang B, Rosloniec EF, Stuart JM, Chiang TM, Kang AH: Characterization of a peptide analog of a determinant of type II collagen that suppresses collagen-induced arthritis. J Immunol 1998, 161:3589-3595.

15. Latham KA, Whittington KB, Zhou R, Qian Z, Rosloniec EF: Ex vivo characterization of the autoimmune $T$ cell response in the HLA-DR1 mouse model of collagen-induced arthritis reveals long-term activation of type II collagen-specific cells and their presence in arthritic joints. JImmunol 2005, 174:3978-3985.

16. Myers $L K$, Tang B, Stuart JM, Kang AH: The role of IL-4 in regulation of murine collagen-induced arthritis. Clin Immunol 2002, 102:185-191.

17. Leung PS, Shu SA, Kenny TP, Wu PY, Tao MH: Development and validation of gene therapies in autoimmune diseases: Epidemiology to animal models. Autoimmun Rev 2010, 9:A400-405.

18. Evans CH, Robbins PD, Ghivizzani SC, Herndon JH, Kang R, Bahnson AB, Barranger JA, Elders EM, Gay S, Tomaino MM, Wasko MC, Watkins SC, Whiteside TL, Glorioso JC, Lotze MT, Wright TM: Clinical trial to assess the safety, feasibility, and efficacy of transferring a potentially anti-arthritic cytokine gene to human joints with rheumatoid arthritis. Hum Gene Ther 1996, 7:1261-1280.

19. Wehling P, Reinecke J, Baltzer AA, Granrath M, Schulitz KP, Schultz C, Krauspe R, Whiteside T, Elder E, Ghivizzani SC, Robbins PD, Evans CH: Clinical responses to gene therapy in joints of two subjects with rheumatoid arthritis. Hum Gene Ther 2009, 20:97-101.

20. Takayanagi H, Juji T, Miyazaki T, lizuka H, Takahashi T, Isshiki M, Okada M, Tanaka Y, Koshihara Y, Oda H, Kurokawa T, Nakamura K, Tanaka S: Suppression of arthritic bone destruction by adenovirus-mediated csk gene transfer to synoviocytes and osteoclasts. J Clin Invest 1999, 104:137-146

21. Zhang H, Yang Y, Horton JL, Samoilova EB, Judge TA, Turka LA, Wilson JM, Chen Y: Amelioration of collagen-induced arthritis by CD95 (Apo-1/ Fas)-ligand gene transfer. J Clin Invest 1997, 100:1951-1957.

22. Ghivizzani SC, Lechman ER, Tio C, Mule KM, Chada S, McCormack JE, Evans $\mathrm{CH}$, Robbins PD: Direct retrovirus-mediated gene transfer to the synovium of the rabbit knee: implications for arthritis gene therapy. Gene Ther 1997, 4:977-982.

23. Nayak S, Herzog RW: Progress and prospects: immune responses to viral vectors. Gene Ther 2010, 17:295-304.

24. Backlund J, Carlsen S, Hoger T, Holm B, Fugger L, Kihlberg J, Burkhardt H, Holmdahl R: Predominant selection of T cells specific for the glycosylated collagen type II epitope (263-270) in humanized transgenic mice and in rheumatoid arthritis. Proc Natl Acad Sci USA 2002, 99:9960-9965

25. Corthay A, Backlund J, Holmdahl R: Role of glycopeptide-specific T cells in collagen-induced arthritis: an example how post-translational modification of proteins may be involved in autoimmune disease. Ann Med 2001, 33:456-465.
26. Michaelsson E, Malmstrom V, Reis S, Engstrom A, Burkhardt H, Holmdahl R: T cell recognition of carbohydrates on type II collagen. J Exp Med 1994, 180:745-749.

27. Dzhambazov B, Nandakumar KS, Kihlberg J, Fugger L, Holmdahl R, Vestberg M: Therapeutic vaccination of active arthritis with a glycosylated collagen type II peptide in complex with MHC class II molecules. J Immunol 2006, 176:1525-1533.

28. Myers LK, Sakurai Y, Rosloniec EF, Stuart JM, Kang AH: An analog peptide that suppresses collagen-induced arthritis. Am J Med Sci 2004, 327:212-216.

doi: $10.1186 /$ ar3074

Cite this article as: Tang et al., Modulation of collagen-induced arthritis by adenovirus-mediated intra-articular expression of modified collagen type I Arthritis Research \& Therapy 2010, 12:R136

\section{Submit your next manuscript to BioMed Central and take full advantage of:}

- Convenient online submission

- Thorough peer review

- No space constraints or color figure charges

- Immediate publication on acceptance

- Inclusion in PubMed, CAS, Scopus and Google Scholar

- Research which is freely available for redistribution

Submit your manuscript at www.biomedcentral.com/submit
C Biomed Central 